\title{
Identification and Characterization of a Novel Whitefly-Transmitted Member of the Family Potyviridae Isolated from Cucurbits in Florida
}

\author{
Scott Adkins, Susan E. Webb, Diann Achor, Pamela D. Roberts, and Carlye A. Baker
}

First author: U.S. Department of Agriculture-Agricultural Research Service, Fort Pierce, FL 34945; second author: University of Florida, Department of Entomology and Nematology, Gainesville 32611; third author: University of Florida, Citrus Research and Education Center, Lake Alfred 33850; fourth author: University of Florida, Department of Plant Pathology, Southwest Florida Research and Education Center, Immokalee 34142; and fifth author: Florida Department of Agriculture and Consumer Services, Division of Plant Industry, Gainesville 32614.

Accepted for publication 24 August 2006.

\begin{abstract}
Adkins, S., Webb, S. E., Achor, D., Roberts, P. D., and Baker, C. A. 2007. Identification and characterization of a novel whitefly-transmitted member of the family Potyviridae isolated from cucurbits in Florida. Phytopathology 97:145-154.

A novel whitefly-transmitted member of the family Potyviridae was isolated from a squash plant (Cucurbita pepo) with vein yellowing symptoms in Florida. The virus, for which the name Squash vein yellowing virus (SqVYV) is proposed, has flexuous rod-shaped particles of $\approx 840$ $\mathrm{nm}$ in length. The experimental host range was limited to species in the family Cucurbitaceae, with the most dramatic symptoms observed in squash and watermelon, but excluded all tested species in the families Amaran-

thaceae, Apocynaceae, Asteraceae, Chenopodiaceae, Fabaceae, Malvaceae, and Solanaceae. The virus was transmitted by whiteflies (Bemisia tabaci) but was not transmitted by aphids (Myzus persicae). Infection by SqVYV induced inclusion bodies visible by electron and light microscopy that were characteristic of members of the family Potyviridae. Comparison of the SqVYV coat protein gene and protein sequences with those of recognized members of the family Potyviridae indicate that it is a novel member of the genus Ipomovirus. A limited survey revealed that SqVYV also was present in watermelon plants suffering from a vine decline and fruit rot recently observed in Florida and was sufficient to induce these symptoms in greenhouse-grown watermelon, suggesting that SqVYV is the likely cause of this disease.
\end{abstract}

Many viruses in multiple genera and families infect cucurbit crops and weeds worldwide $(6,14,34)$. Recent surveys for insecttransmitted viruses in Florida cucurbit crops have shown that Papaya ringspot virus type W (PRSV-W), Zucchini yellow mosaic virus (ZYMV), and Watermelon mosaic virus (WMV, formerly WMV-2) are prevalent within the state (51). Members of the genus Potyvirus in the family Potyviridae, including PRSV-W, ZYMV, and WMV, are among the most common, economically important, and best-characterized viruses infecting cucurbits (29).

Cucumber vein yellowing virus (CVYV), genus Ipomovirus in the family Potyviridae, has been reported to be an economic problem in the Middle East for many years $(11,19)$ and recently has become widespread throughout the Mediterranean region $(2,15,27,55)$. CVYV is a relatively unusual member of the family Potyviridae in that it is transmitted by whiteflies $(11,19,28)$. Under current taxonomic guidelines, CVYV is one of three accepted members (with Sweet potato mild mottle virus [SPMMV] and Cassava brown streak virus [CBSV]) and one tentative member (Sweet potato yellow dwarf virus [SPYDV]) of the genus Ipomovirus $(4,12,13,20,25)$. These viruses are distinct from the whitefly-transmitted begomoviruses and criniviruses commonly found in tomato and bean in Florida $(5,33,54)$.

During a survey of cucurbit viruses in Hillsborough County, FL, in October 2003, a sample was collected from a squash plant (Cucurbita pepo) with vein yellowing symptoms. This sample,

Corresponding author: S. Adkins; E-mail address: SAdkins@ushrl.ars.usda.gov

* The $\boldsymbol{e}$-Xtra logo stands for "electronic extra" and indicates that Figure 1 appears in color online.

DOI: 10.1094/PHYTO-97-2-0145

This article is in the public domain and not copyrightable. It may be freely reprinted with customary crediting of the source. The American Phytopathological Society, 2007
1 of 40 collected from the same field, was found to be infected with a virus not previously described in Florida. The other 39 samples all tested positive for PRSV-W. Serological and molecular tests (double-antibody sandwich enzyme-linked immunosorbent assay [DAS-ELISA], nucleic acid hybridization, and reversetranscription polymerase chain reaction [RT-PCR]) for 30 viruses known to infect cucurbits in Florida and elsewhere were negative (53). Initial light microscopic examination for inclusion bodies and electron microscopy of leaf dips revealed no known virusinduced structures or virions, and double-stranded (ds)RNA analysis revealed no viral-associated dsRNA.

In this article, we present biological and molecular characterization of this Florida cucurbit virus, for which the name Squash vein yellowing virus (SqVYV) is proposed. The host range of this virus, coupled with analysis of its transmission and deduced coat protein $(\mathrm{CP})$, suggest that it is a novel, whitefly-transmitted member of the genus Ipomovirus in the family Potyviridae. We also report evidence of SqVYV in Florida watermelon suffering from a vine decline and fruit rot that has caused severe losses since 2003 in spring and fall plantings, where rapid disease progress may lead to increases in incidence from 10 to $>80 \%$ within a week $(37,38)$. Finally, we show that SqVYV is sufficient to induce vine decline and fruit necrosis symptoms in the greenhouse, suggesting that it is the likely cause of this disease.

\section{MATERIALS AND METHODS}

Virus source, maintenance, isolation, and characterization. The original squash isolate and subsequent watermelon isolates of SqVYV were maintained in squash $(C$. pepo) cv. Prelude II (Seminis Seeds, Oxnard, CA) plants in the greenhouse by mechanical transmission using $20 \mathrm{mM}$ sodium phosphate buffer $(\mathrm{pH} 7.0)$ containing $0.1 \%(\mathrm{wt} / \mathrm{vol})$ sodium sulfite and $1 \%(\mathrm{wt} / \mathrm{vol})$ Celite. 
Virions were isolated from leaves of inoculated squash as described for Hibiscus chlorotic ringspot virus by Waterworth and colleagues (50) and analyzed by electron microscopy on 300-mesh formvar-coated copper grids after staining with 5\% (wt/vol) uranyl acetate. Measurements of 100 particles representative of SqVYV were used to determine a mean particle length.

Host range determination. An experimental host range for SqVYV was determined by mechanically inoculating 22 species in eight families with the virion preparation. All experimental hosts were grown from seed (except Adenium obesum, which was propagated by cuttings from a virus-free stock plant) and maintained in an air-conditioned greenhouse under natural lighting with a daytime high temperature of $30^{\circ} \mathrm{C}$. All plants were mechanically inoculated with virions in the phosphate-sulfite buffer indicated above at the two- to three-true-leaf stage (except mature watermelon plants, which were inoculated 10 weeks post-seeding). Plants were evaluated weekly for symptoms. Local and systemic infection was confirmed by one or more of the following methods: (i) inoculation of squash cv. Prelude II with washed inoculated or upper uninoculated leaves, homogenized in the phosphate-sulfite buffer, followed by evaluation of vein yellowing 2 weeks later; (ii) light microscopic examination of virus-induced inclusion bodies; or (iii) RT-PCR of the inoculated experimental host plants as outlined below.

Electron microscopy. Samples from the crown, stem, and leaves were collected from mock-inoculated (buffer only) and SqVYV-infected watermelon and squash plants and prepared for transmission electron microscopy (TEM). The samples were placed in $3 \%$ glutaraldehyde (vol/vol) in $0.1 \mathrm{M}$ potassium phosphate buffer ( $\mathrm{pH}$ 7.2) for $4 \mathrm{~h}$ at room temperature, then washed in buffer and post-fixed for $4 \mathrm{~h}$ at room temperature in $2 \%$ osmium tetroxide (wt/vol) in the same buffer. They then were washed in buffer, dehydrated in an acetone series, and embedded in Spurr's resin (45). Blocks from leaf and stem tissue were thick sectioned $(1 \mu \mathrm{m})$, stained with methylene blue or Azure A (AA) and basic fuchsin (41), and studied with light microscopy for effects of virus infection. The same blocks then were trimmed, thin sectioned $(90 \mathrm{~nm})$, stained with $2 \%$ (wt/vol) aqueous uranyl acetate and Reynolds (35) lead citrate, and searched with a Morgagni 268 TEM (FEI, The Netherlands) for virions and inclusions.

Light microscopy. Leaf strips for the light microscope were prepared according to Christie and Edwardson (10). Epidermal strips were removed from the underside of leaves or from stems and petioles and put into a $5 \%(\mathrm{vol} / \mathrm{vol})$ solution of Triton X-100 to remove plastids. This was followed by staining in Calcomine Orange and Luxol Brilliant Green (OG). Other tissue was stained directly in AA. After 10 to $15 \mathrm{~min}$ in the stain, the tissue was destained and mounted on slides in Euparal. The slides were viewed on a light microscope for the presence or absence of viral inclusion bodies.

Insect source, maintenance, and transmission studies. Adult whiteflies (Bemisia tabaci, B strain $=$ B. argentifolii Bellows \& Perring) of mixed ages (newly enclosed to 4 days) were obtained from a colony maintained on cotton (Gossypium hirsutum) and collard (Brassica oleracea var. acephala) as described by Chen et al. (9). Green peach aphids (Myzus persicae Sulzer) were collected from a colony maintained on bell pepper (Capsicum annuum) (52). Squash cv. Prelude II was used for both source and test plants. Plants were grown in a 3:1 ( $\mathrm{vol} / \mathrm{vol})$ mixture of MetroMix Ag Lite Mix (Sun Gro Horticulture, Bellevue, WA) and pasteurized sand (Quikrete, Atlanta, GA). The virus was maintained as described above.

Whitefly transmission. In an initial experiment, $\approx 100$ adult whiteflies were released into a 61-by-61-by-61-cm cage consisting of a frame constructed of PVC pipe $(1.3 \mathrm{~cm}$ in diameter) enclosed in an organdy cover containing one SqVYV-infected squash plant at 10 days postinoculation. In addition, $\approx 100$ adult whiteflies also were released into a second cage containing one uninfected squash plant. After a 24-h acquisition access period, six 2-week-old squash plants were added to each cage. After a 2-day inoculation access period, the plants were shaken and removed from the cages. Plants were treated with pymetrozine (Fulfill; Syngenta, Greensboro, NC) and returned to the greenhouse. Plants were monitored for symptom development for 10 days.

In a second, larger experiment, $>1,000$ adult whiteflies were released into a cage containing three SqVYV-infected squash plants at 2 weeks postinoculation. Additional whiteflies were added to a second cage containing uninfected squash plants of the same age. After a 45-h acquisition access period, 10 uninfected 16-day-old squash plants were added to the cage with the infected plants. After a 2-h inoculation access period, the plants were shaken and removed from the cage and a second set of 10 plants was added to the cage for $2 \mathrm{~h}$. Plants were insecticide treated as above and returned to the greenhouse. On the following day, two sets of 10 watermelon plants (cv. Crimson Sweet) were exposed for $2 \mathrm{~h}$ each to the remaining whiteflies, which now had been feeding on infected squash for $65 \mathrm{~h}$. Plants were shaken to remove whiteflies and insecticide treated as above, prior to being returned to the greenhouse. Control plants of both squash and watermelon were exposed for $24 \mathrm{~h}$ to whiteflies that had access to uninfected squash and then treated and moved to the greenhouse. Plants were examined for symptoms for 2 weeks.

Aphid transmission. Aphids were transferred in groups of three or four to petri dishes lined with moistened filter paper and starved for 1 to $1.5 \mathrm{~h}$ before transfer to a squash leaf from a plant inoculated with SqVYV 2 weeks earlier. Aphids were allowed a 1.5-min acquisition access period on the infected leaf followed by a 1.5-min inoculation access period (three aphids per plant) on a 10-day-old uninfected squash seedling with one true leaf. Aphids were removed from the plants and destroyed. In all, 25 plants were exposed to aphids given access to an SqVYV-infected leaf, 4 plants were exposed to aphids given access to an uninfected leaf, and 1 plant was exposed to aphids given access to a leaf infected with the highly aphid-transmissible PRSV-Tigre (51). Plants were returned to the greenhouse and observed for 2 weeks for symptom development. A second aphid transmission experiment used source plants that had been mechanically inoculated with either SqVYV or PRSV-W.

Cloning and analysis of the CP gene. Viral genomic RNA was extracted from virions according to previously described methods (30). First-strand cDNA was synthesized by Moloney murine leukemia virus reverse transcriptase (Promega Corp., Madison, WI) at $45^{\circ} \mathrm{C}$ for 45 min with standard methods (40) using a previously described degenerate potyvirus $3^{\prime}$ terminus primer (18). This was followed by 30 cycles of PCR amplification with Taq polymerase (Promega Corp.) at $94^{\circ} \mathrm{C}$ for $30 \mathrm{~s}, 55^{\circ} \mathrm{C}$ for $30 \mathrm{~s}$, and $72^{\circ} \mathrm{C}$ for $30 \mathrm{~s}$ using the above primer and a second degenerate potyvirus primer (18) located within the NIb gene. Products were ligated into pGEM-T (Promega Corp.).

Selected clones were sequenced on an ABI3730XL automated sequencer at the USHRL DNA Sequencing Support Laboratory. Sequences were edited in VectorNTI (InforMax, North Bethesda, MD) and subjected to BLAST searches (3). The only sequences producing significant alignments from BLASTX queries were the CPs of recognized members of the genus Ipomovirus in the family Potyviridae and, to a much lesser extent, members of the genus Tritimovirus. Overlapping clones were aligned manually and with ClustalX version 1.81 (47) to assemble the $3^{\prime}$ terminus of the SqVYV genome (GenBank accession no. DQ812125). The putative NIb/CP cleavage site (GEIELQ/A) of the deduced protein was identified by comparison with the CVYV (20) and consensus family Potyviridae cleavage sites $(36,43)$.

Multiple alignments of the $\mathrm{CP}$ gene and deduced protein of SqVYV and representative recognized members of all six genera in the family Potyviridae were prepared using ClustalX version 
1.81. Percent nucleotide and amino acid identities were calculated using GeneDoc (31). Phylogenetic analyses used the conserved core of the CPs and PHYLIP version 3.65 (17) programs PROTDIST and NEIGHBOR to generate neighbor-joining trees, which subsequently were displayed in TreeView 1.6.6 (32). Brome streak mosaic virus (BrSMV) of the genus Tritimovirus was used as an outgroup because it was the most closely related (29\% amino acid identity in the conserved core of the CP) nonipomovirus member of the family Potyviridae. The significance of branching order was assessed by bootstrap resampling of 1,000 replicates using the SEQBOOT program of PHYLIP.
RT-PCR detection of SqVYV. An RT-PCR assay was developed for SqVYV using the CP gene sequence determined above. First-strand cDNA was synthesized as outlined above using a previously described degenerate potyvirus $3^{\prime}$ terminus primer (18). A portion of the SqVYV CP gene then was amplified by PCR using a viral sense primer (5'-GATCTTGCCGCGAAAGAAGC- $3^{\prime}$ ) that is identical to the nucleotide sequence just downstream of the $5^{\prime}$ terminus and a viral complementary primer $\left(5^{\prime}-\right.$ CGCGTCCTTCCTCTCCAGGC-3') that is just upstream of the $3^{\prime}$ terminus of the deduced $\mathrm{CP}$ gene by 30 cycles with Taq polymerase (Promega Corp.) at $94^{\circ} \mathrm{C}$ for $30 \mathrm{~s}, 55^{\circ} \mathrm{C}$ for $30 \mathrm{~s}$, and $72^{\circ} \mathrm{C}$
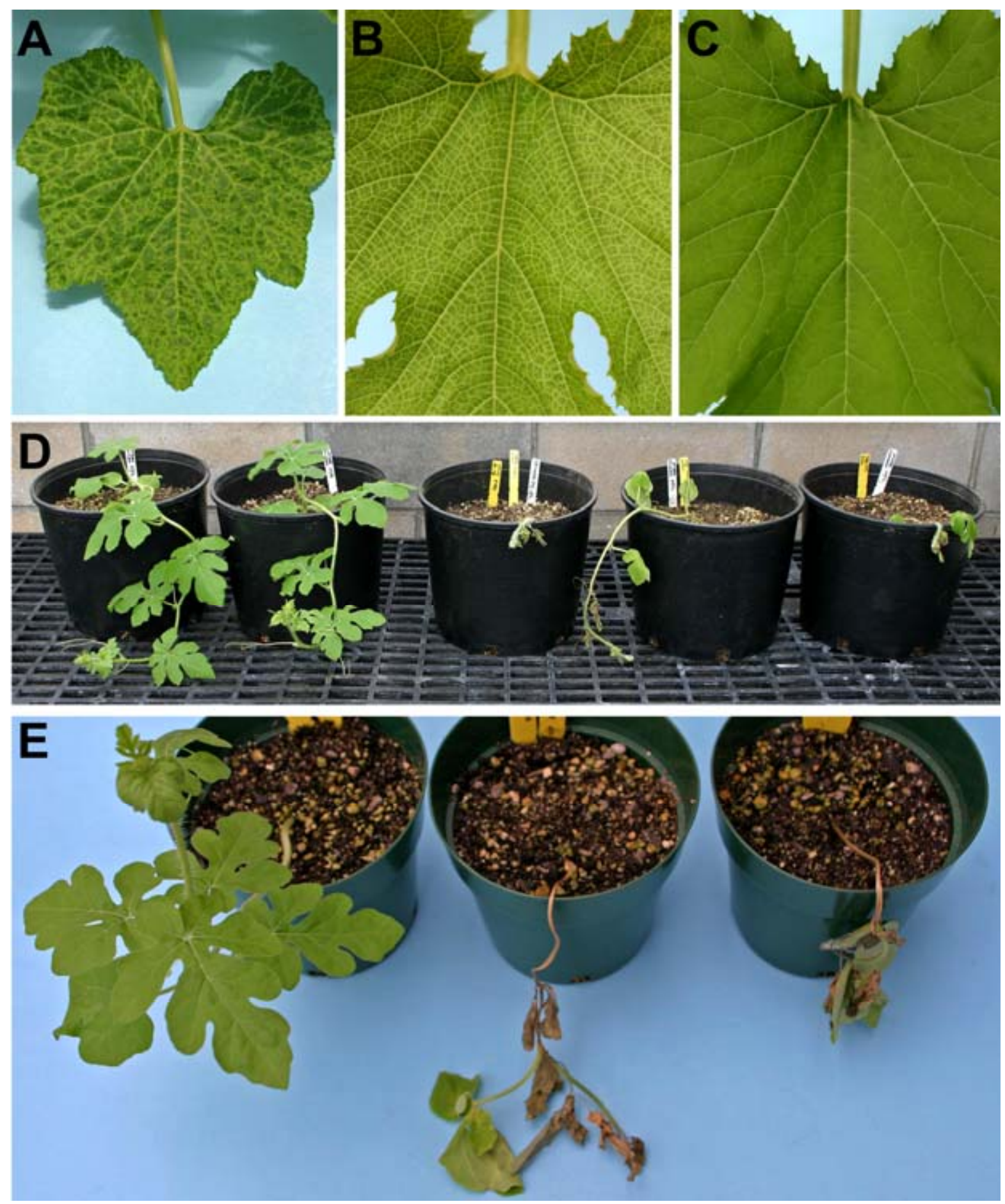

Fig. 1. Cucurbit plants infected with Squash vein yellowing virus (SqVYV). A, Squash cv. Prelude II and B, cv. Burpee zucchini hybrid with vein yellowing symptoms at 20 days postinoculation (dpi) with SqVYV. C, Corresponding mock-inoculated Burpee zucchini hybrid is shown for comparison. D, Watermelon cv. Crimson Sweet at 9 dpi and E, cv. Carolina Cross \#183 at 13 dpi with SqVYV showing systemic wilt and necrosis. Mock-inoculated plants are shown for comparison (D, two leftmost plants and $\mathbf{E}$, leftmost plant). 
for $30 \mathrm{~s}$. The predicted length of the amplified DNA product was $957 \mathrm{bp}$. Products were analyzed by electrophoresis on native $1 \%$ agarose gels and detected by ethidium bromide staining.

\section{RESULTS}

Isolation of SqVYV virions. An agent was mechanically transmitted from the original 2003 squash field sample to squash plants as determined by the development of vein yellowing symptoms (Fig. 1A and B). Isolates from subsequent watermelon field samples were maintained in the same manner. Suspecting the presence of a spherical virus, a typical carmovirus isolation protocol was tested on symptomatic squash leaves, resulting in an infectious preparation as judged by inoculation to squash plants. Electron microscopic examination of this partially purified preparation revealed flexuous rod-shaped particles (mean length of $837 \mathrm{~nm}$ ) (Fig. 2A) that were typical of those described for members of the family Potyviridae. Subsequent molecular analysis described below provided additional support for the presence of a member of the family Potyviridae; however, when a typical potyvirus isolation protocol was later used, no infectivity was recovered.

Host range determination. An experimental host range for SqVYV was determined by mechanical inoculation of 22 species (Table 1), including common hosts reported for other members of the family Potyviridae. No evidence of infection was detected in any of the tested Amaranthaceae, Apocynaceae, Asteraceae, Cheno- podiaceae, Fabaceae, Malvaceae, or Solanaceae species, including several common virus indicator hosts. In fact, infection was confirmed only in the family Cucurbitaceae. Plants in the genera Cucurbita (pumpkin, tropical pumpkin, and four squash cultivars) and Luffa (luffa) developed characteristic vein yellowing in inoculated and upper, uninoculated leaves (Fig. 1A and B), whereas cultivated members of the genus Cucumis (cantaloupe and cucumber) developed only transient vein yellowing in the uninoculated leaves immediately above the inoculated leaves. SqVYV was detectable by back inoculation to squash and RT-PCR from these symptomatic leaves but nowhere else in the plant (data not shown). However, after a few days when the symptoms disappeared, SqVYV was no longer detectable in these previously symptomatic leaves (data not shown). The lone exception in the genus Cucumis was the melon breeding line WMR29, which developed systemic vein yellowing symptoms. All plants in the genus Citrullus (five watermelon cultivars) developed mild vein yellowing and chlorotic lesions on inoculated leaves followed by systemic wilting and necrosis leading to plant death within 7 to 10 days (Fig. 1D and E). Older, more mature plants grown in the greenhouse developed systemic wilt and fruit symptoms within 14 days, including rind necrosis and discoloration (Fig. 3A and B).

Electron and light microscopy. Pinwheel-like inclusion bodies typical of the family Potyviridae were observed in thin sections of SqVYV-infected watermelon and squash tissue (Fig. 2B) by electron microscopy. Cylindrical inclusions $(16,46)$ also were seen at
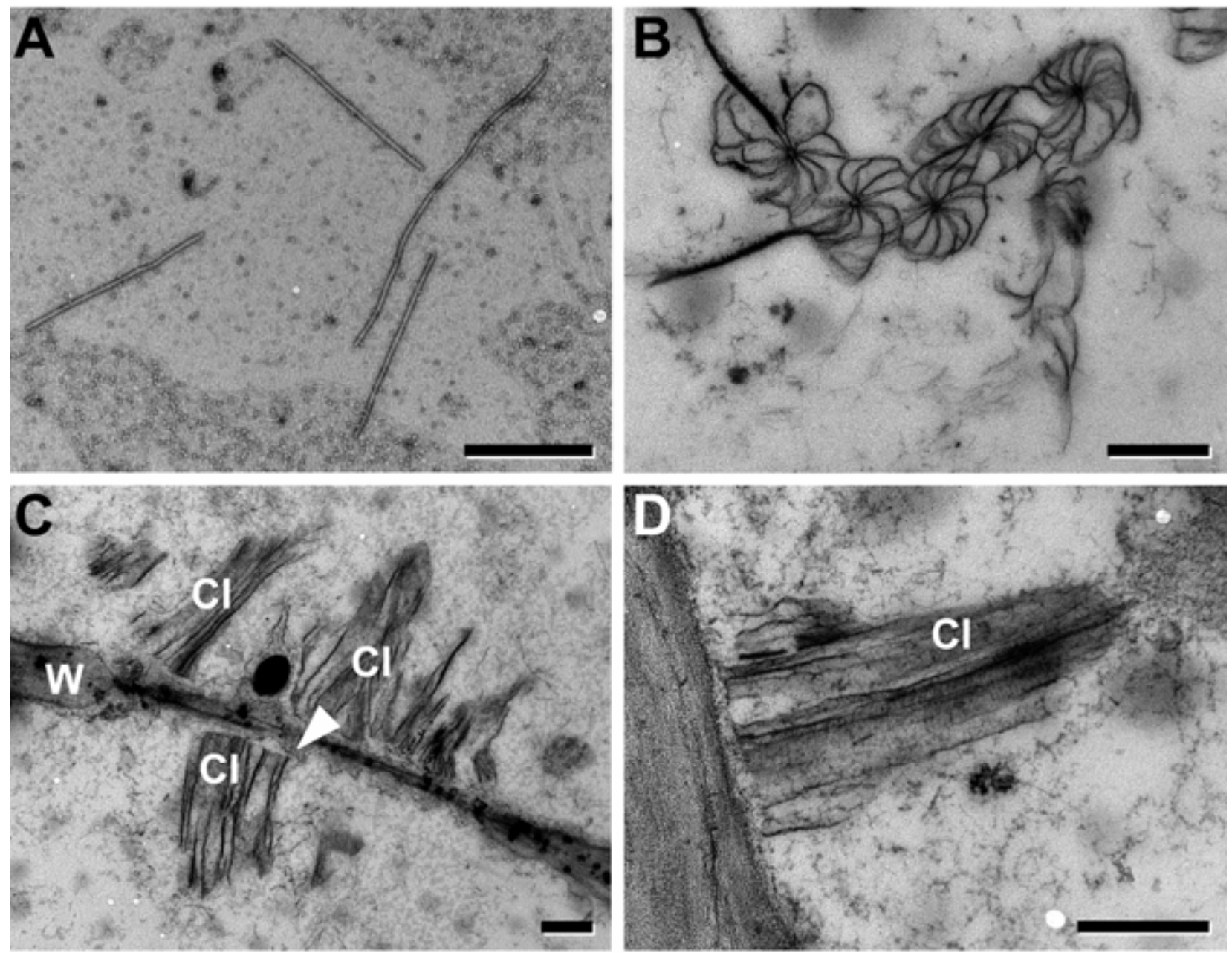

Fig. 2. Characterization of Squash vein yellowing virus (SqVYV) virions and inclusions by electron microscopy is consistent with it being a member of the family Potyviridae. A, Electron micrograph of partially purified virions of SqVYV shows typical Potyviridae morphology. B to D, Characteristic Potyviridae-induced structures in phloem parenchyma cells of SqVYV-infected cucurbits. B, Watermelon leaf section showing pinwheel inclusions. C and $\mathbf{D}$, Squash stem sections showing cylindrical inclusions (CI) (46) associated with the cell wall (W) and plasmalemma (arrow). All scale bars represent $500 \mathrm{~nm}$. 
the cell periphery attached to the plasmalemma along the cell wall of SqVYV-infected squash (Fig. 2C and D). All inclusions were found in phloem tissue (parenchyma and companion cells).

In light microscopy, cylindrical inclusions were found in SqVYV-infected watermelon and squash along the plasmalemma of the cell wall of epidermal tissue stained with OG (Fig. 4A). These inclusions were not observed in epidermal tissue stained with AA (data not shown). However, additional inclusions that stained with OG and light pink with AA were observed in vascular tissue, indicating the presence of protein and RNA, respectively (data not shown). Nuclei were observed in the vascular tissue cells with these inclusions in both stains, confirming that this was phloem tissue (parenchyma and companion cells). No cylindrical inclusions were observed in uninfected squash or watermelon tissue with either stain (Fig. 4B).

Whitefly transmission. In the first experiment, three of six squash plants began developing symptoms 8 days after exposure to whiteflies fed on SqVYV-infected plants. No control plants developed symptoms. Whitefly transmission of SqVYV was confirmed by RT-PCR (data not shown).

In the second experiment, some of the squash plants began developing symptoms 4 days after exposure to whiteflies fed on SqVYV-infected plants. After 1 week, 10 of 10 of the first set of squash plants exposed to whiteflies and 7 of 10 of the second set had developed pronounced vein yellowing symptoms. Watermelon plants developed symptoms more slowly, with one plant showing symptoms at 7 days post-exposure. By 11 days postexposure, 8 of 10 of the first set of watermelon plants and 1 of 10 of the second set showed curling and yellowing of the new growth. By the following day, a few of the watermelon plants had yellow petioles and were beginning to collapse. No control plants developed symptoms. Whitefly transmission of SqVYV was confirmed by RT-PCR (Fig. 5, lanes 6 to 9).

Aphid transmission. No plants developed symptoms in the first experiment, except for the plant exposed to aphids that had access to PRSV-Tigre-infected plants (infection confirmed by DAS-ELISA with antiserum provided by D. E. Purcifull). In the second experiment, 0 of 25 plants exposed to aphids that had access to SqVYV-infected plants developed symptoms, whereas 13 of 25 plants exposed to aphids that had access to PRSV-Winfected plants developed typical symptoms. PRSV-W infection was confirmed by DAS-ELISA.

CP sequence analysis. The nucleotide sequence of the $3^{\prime}$ terminus of the SqVYV genome, including the putative CP portion of the polyprotein gene, was determined from several overlapping clones. The $\mathrm{CP}$ portion of the polyprotein gene consists of 1,077 nucleotides and encodes a protein of 358 amino acids with a predicted translation product of $39.4 \mathrm{kDa}$. The deduced SqVYV $\mathrm{CP}$ contains, within the core region, the conserved $\mathrm{R}$ and $\mathrm{D}$ residues reported to be essential for virion assembly of all members of the family Potyviridae (48). A highly conserved DAG motif found in the CPs of members of the genus Potyvirus occurs at residues 52 to 54 from the $\mathrm{N}$ terminus of the SqVYV CP. The only sequences producing significant alignments from BLASTX and BLASTP queries were the CPs of members of the genus Ipomovirus and, to a much lesser extent, members of the genus Tritimovirus, including many strains or isolates of some species.

The SqVYV CP was aligned with the CPs of representative recognized members of each of the six genera comprising the family Potyviridae. The SqVYV CP-deduced amino acid sequence exhibited the following identities with the indicated genus: 34 to $66 \%$ (Ipomovirus), 20 to $21 \%$ (Tritimovirus), 16 to

TABLE 1. Experimental host range and symptoms of Squash vein yellowing virus

\begin{tabular}{|c|c|c|c|}
\hline Family & Species & Common name & Symptoms ${ }^{b}$ \\
\hline Amaranthaceae & Gomphrena globosa & Globe amaranth & $-1-$ \\
\hline Apocynaceae & Adenium obesum & Desert rose & $-1-$ \\
\hline Asteraceae & Emilia sonchifolia & Red tassel flower & $-1-$ \\
\hline \multirow[t]{2}{*}{ Chenopodiaceae } & Chenopodium quinoa & Lambsquarters & $-1-$ \\
\hline & Spinacia oleracea & Spinach & $-1-$ \\
\hline \multirow[t]{16}{*}{ Cucurbitaceae } & Citrullus lanatus cv. Carolina Cross \#183 & Watermelon & MVY,CL/SWN \\
\hline & C. lanatus cv. Crimson Sweet & Watermelon & MVY,CL/SWN \\
\hline & C. lanatus cv. Mickey Lee & Watermelon & MVY,CL/SWN \\
\hline & C. lanatus cv. Sangria & Watermelon & MVY,CL/SWN \\
\hline & C. lanatus cv. Tiger Baby & Watermelon & MVY,CL/SWN \\
\hline & Cucumis melo cv. Burpee Sweet 'n' Early Hybrid & Cantaloupe & $-/ \mathrm{TVY},-$ \\
\hline & C. melo WMR29 & & VY/VY \\
\hline & C. sativus cv. Burpee Straight 8 & Cucumber & $-/ \mathrm{TVY},-$ \\
\hline & C. sativus cv. Burpee Sweet Success & Cucumber & $-/ \mathrm{TVY},-$ \\
\hline & Cucurbita maxima cv. Big Max & Pumpkin & MVY,CL/VY \\
\hline & C. moschata cv. Eldorado & Tropical pumpkin & MVY,CL/VY \\
\hline & C. реро cv. Burpee zucchini hybrid & Squash & $\mathrm{CL} / \mathrm{VY}$ \\
\hline & C. pepo cv. Burpee Fordhook zucchini & Squash & $\mathrm{CL} / \mathrm{VY}$ \\
\hline & C. pepo cv. Black Beauty zucchini & Squash & $\mathrm{CL} / \mathrm{VY}$ \\
\hline & C. pepo cv. Prelude II & Squash & VY/VY \\
\hline & Luffa acutangula & Luffa & MVY,CL/VY \\
\hline \multirow[t]{5}{*}{ Fabaceae } & Arachis hypogaea & Peanut & $-1-$ \\
\hline & Glycine max & Soybean & $-1-$ \\
\hline & Phaseolus vulgaris cv. Kentucky Wonder & Green bean & $-1-$ \\
\hline & Vicia faba & Faba bean & $-1-$ \\
\hline & Vigna unguiculata & Blackeye cowpea & $-1-$ \\
\hline \multirow[t]{3}{*}{ Malvaceae } & Abelmoschus esculentus cv. Clemson Spineless & Okra & $-1-$ \\
\hline & Gossypium hirsutum cv. DES 607 & Cotton & $-1-$ \\
\hline & Hibiscus cannabinus & Kenaf & $-1-$ \\
\hline \multirow[t]{2}{*}{ Solanaceae } & Lycopersicon esculentum cv. Florida 47 & Tomato & $-1-$ \\
\hline & Nicotiana benthamiana & & $-1-$ \\
\hline
\end{tabular}

${ }^{a}$ Family and species names according to Brako et al. (8) and U.S. Department of Agriculture, NRCS (49).

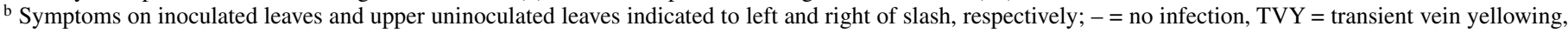
MVY = mild vein yellowing, VY = vein yellowing, $\mathrm{CL}=$ chlorotic lesions, and SWN = systemic wilt and necrosis. Local and systemic infection confirmed by (i) inoculation of squash cv. Prelude II with washed inoculated or upper uninoculated leaves homogenized in $20 \mathrm{mM}$ sodium phosphate buffer (pH 7.0 ) containing $0.1 \%$ (wt/vol) sodium sulfite and $1 \%$ (wt/vol) Celite, (ii) examination of virus-induced inclusion bodies by light microscopy, or (iii) reverse-transcription polymerase chain reaction. 
19\% (Potyvirus), 14 to $16 \%$ (Rymovirus), 11 to $12 \%$ (Macluravirus), and 9 to $13 \%$ (Bymovirus). Among the recognized members of the family Potyviridae, the CP of the ipomovirus CVYV $(20,25)$ shared the highest overall nucleotide and amino acid identity with SqVYV, 64 and $66 \%$, respectively. The other two ipomoviruses for which sequence data is available, CBSV and SPMMV (12,13), shared 57 and $39 \%$ nucleotide identity and 55 and $34 \%$ amino acid identity, respectively, with the SqVYV CP.
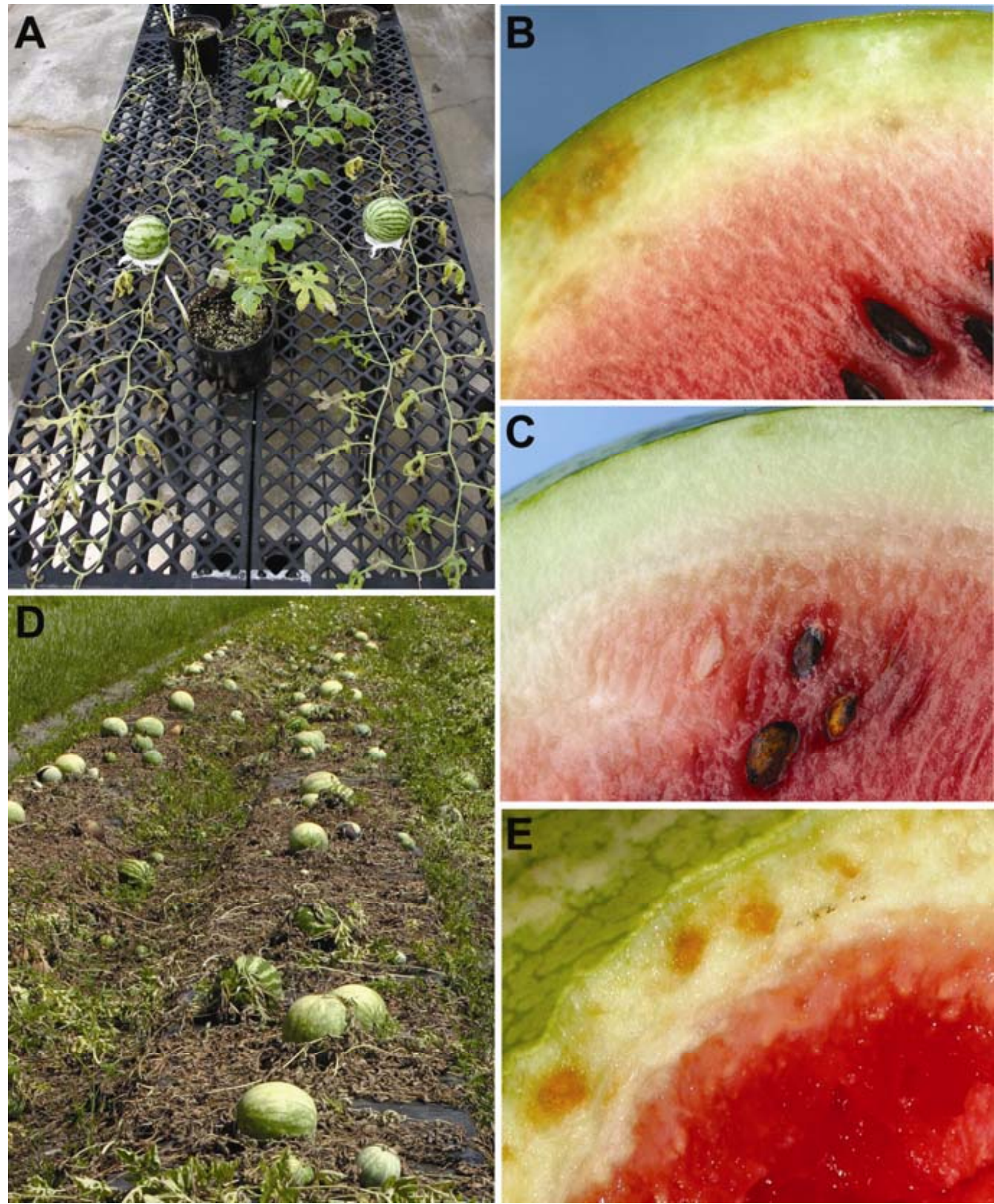

Fig. 3. Mechanical inoculation of greenhouse-grown watermelon with partially purified virions of Squash vein yellowing virus (SqVYV) shows that SqVYV is sufficient for vine decline and fruit rot symptoms. A, SqVYV-inoculated watermelon plants wilting and dying on each side of bench at 14 days postinoculation. Mock-inoculated watermelon plant is shown in middle of bench for comparison. B, Fruit from SqVYV-inoculated plant showing rind necrosis and discoloration. C, Fruit from mock-inoculated plant showing normal white to light-green rind. D, Field symptoms of vine decline and E, rind necrosis and discoloration for comparison. 
The $3^{\prime}$ untranslated region (UTR) of SqVYV shared nucleotide identities of 44, 34, and $22 \%$ with CVYV, CBSV, and SPMMV, respectively.

Comparison of the conserved core of the family Potyviridae $\mathrm{CP}$ amino acid sequences previously has been shown to provide a meaningful measure of relatedness between species $(1,44,48)$. An alignment of the conserved core of the $\mathrm{CP}$ amino acid sequences was prepared for the same representative recognized members of each of the six genera composing the family Potyviridae whose complete CPs were aligned above. As expected, the amino acid sequence of the conserved core of the SqVYV CP shared higher identities with the conserved core of the CPs of other members of the family Potyviridae than was observed in the comparisons of the entire CPs reported above. Amino acid identities with the conserved core of the SqVYV CP of the indicated genus were: 49 to $79 \%$ (Ipomovirus), 28 to 29\% (Tritimovirus), 23 to 26\%, (Potyvirus), 22 to $23 \%$ (Rymovirus), 16 to $18 \%$ (Macluravirus), and 13 to $17 \%$ (Bymovirus). Among the recognized ipomoviruses, the conserved core of the SqVYV CP shared amino acid identities of 79, 73, and 49\% with CVYV, CBSV, and SPMMV, respectively.

This alignment of the conserved core of the $\mathrm{CP}$ amino acid sequences was used to infer a phylogenetic tree (Fig. 6) that clustered members of the family Potyviridae by genus as previously demonstrated $(1,4)$. The three accepted ipomoviruses
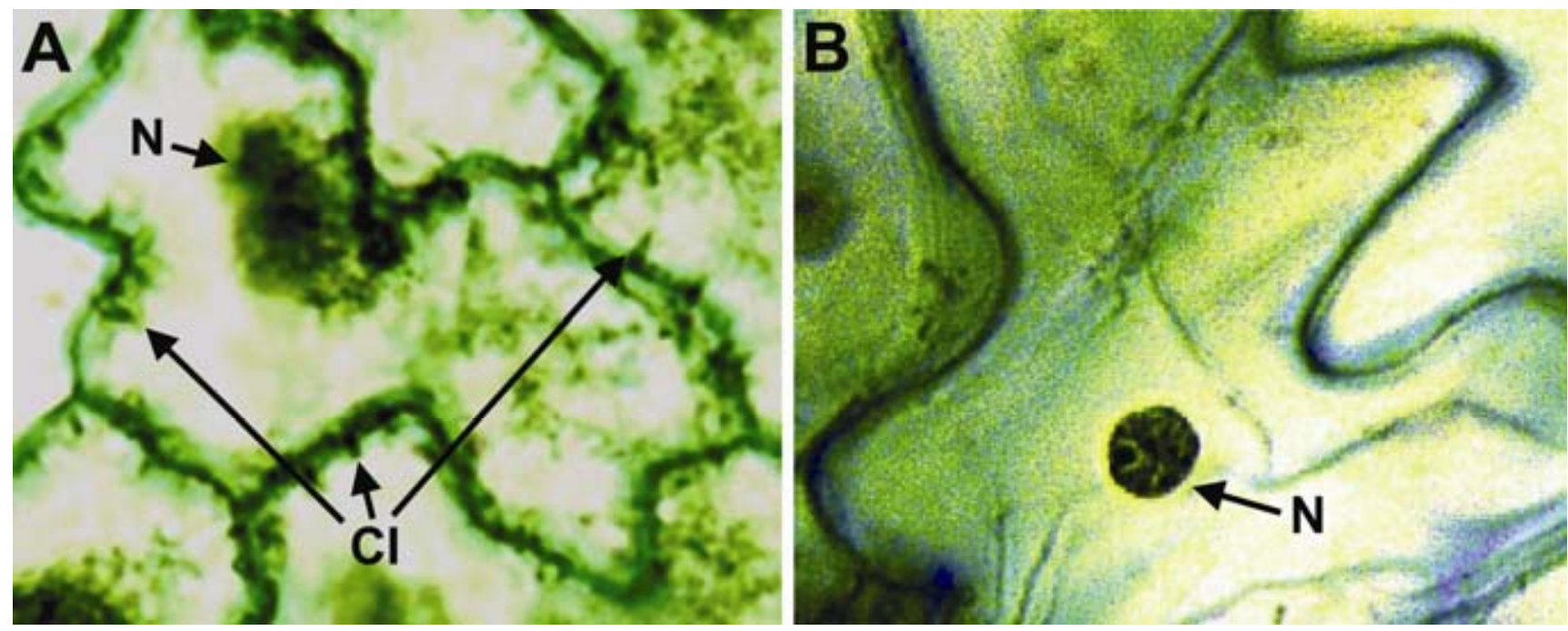

Fig. 4. Viral inclusions induced by Squash vein yellowing virus (SqVYV) as seen in the light microscope. A, Squash leaf strip (from SqVYV-infected plant) stained in Orange-Green showing a nucleus $(\mathrm{N})$ and cylindrical inclusions (CI) along the cell wall. B, Watermelon leaf strip (from uninfected plant) stained in Orange-Green showing a nucleus $(\mathrm{N})$ but no inclusions.

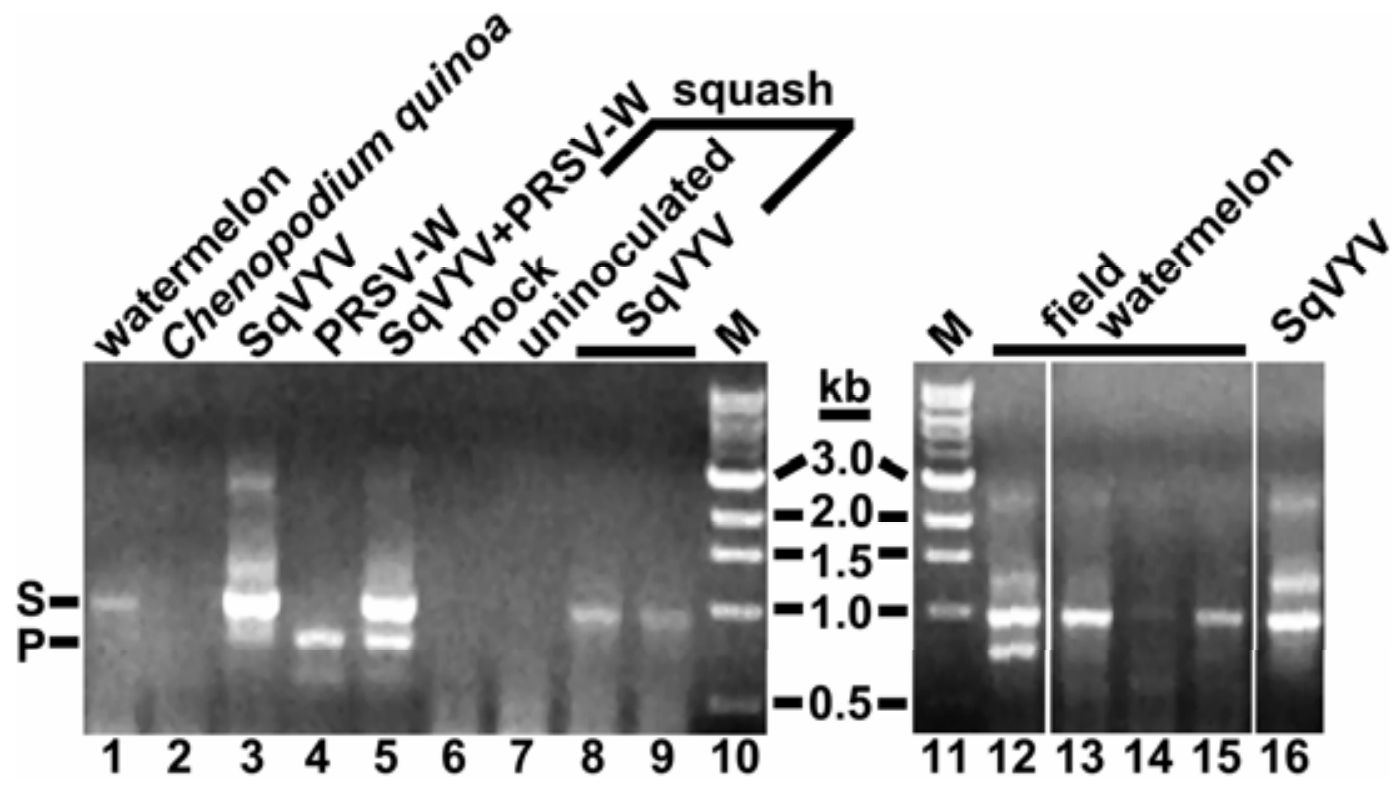

Fig. 5. Detection of Squash vein yellowing virus (SqVYV) by reverse-transcription polymerase chain reaction (RT-PCR) in mechanically and whitefly-inoculated greenhouse and naturally infected field plants. Total RNA from indicated plants was used as template for RT-PCR amplification with primers based on the SqVYV coat protein gene sequence, analyzed by native gel electrophoresis on 1\% agarose gels, and stained with ethidium bromide. Lanes 1 and 2: RT-PCR products from host range studies by mechanical inoculation with SqVYV. Lanes 3, 4, and 16: Positive control RT-PCR products from watermelon plants mechanically inoculated with the indicated virus (SqVYV or Papaya ringspot virus type W [PRSV-W]). Lane 5: Positive control RT-PCR products from a mixture of SqVYV and PRSV-W RNA templates used to generate the products in lanes 3 and 4. Lanes 6 to 9: RT-PCR products from squash test plants in a whitefly transmission experiment. RNA template in lane 7 was from an uninoculated plant, whereas RNA templates in lanes 6, 8, and 9 were from whitefly-inoculated plants using uninfected (lane 6) or SqVYV-infected (lanes 8 and 9) squash source plants. Lanes 12 to 15: RT-PCR products from watermelon plants in fields suffering from vine decline in southwest Florida in spring 2004 (lane 12) and in west-central Florida in fall 2005 (lanes 13 to 15). Lanes 10 and 11: Markers with size in kilobases (kb) indicated. Relative positions of SqVYV (S) and PRSV-W (P) RT-PCR products are indicated to the left of the gel. 
(SPMMV, CVYV, and CBSV) always clustered in our analyses and SqVYV always clustered with these three species, providing additional support for the biological and transmission data suggesting that SqVYV is a member of the genus Ipomovirus.

RT-PCR detection of SqVYV. Using SqVYV virion RNA or total RNA extracted from various plant species, products of the expected size of $957 \mathrm{bp}$ were observed in agarose gels following RT-PCR amplification (Fig. 5, lanes 1, 3, 8, 9, and 13 to 16). No amplification products from uninfected plants were obtained (Fig. 5, lanes 2, 6, and 7). However, amplification products of a shorter length (787 bp) were obtained from PRSV-W virion RNA or total RNA from PRSV-W-infected plants (Fig. 5, lane 4). The usefulness of this phenomenon to permit detection of mixed SqVYV/ PRSV-W infections was demonstrated later (Fig. 5, lanes 5 and 12).

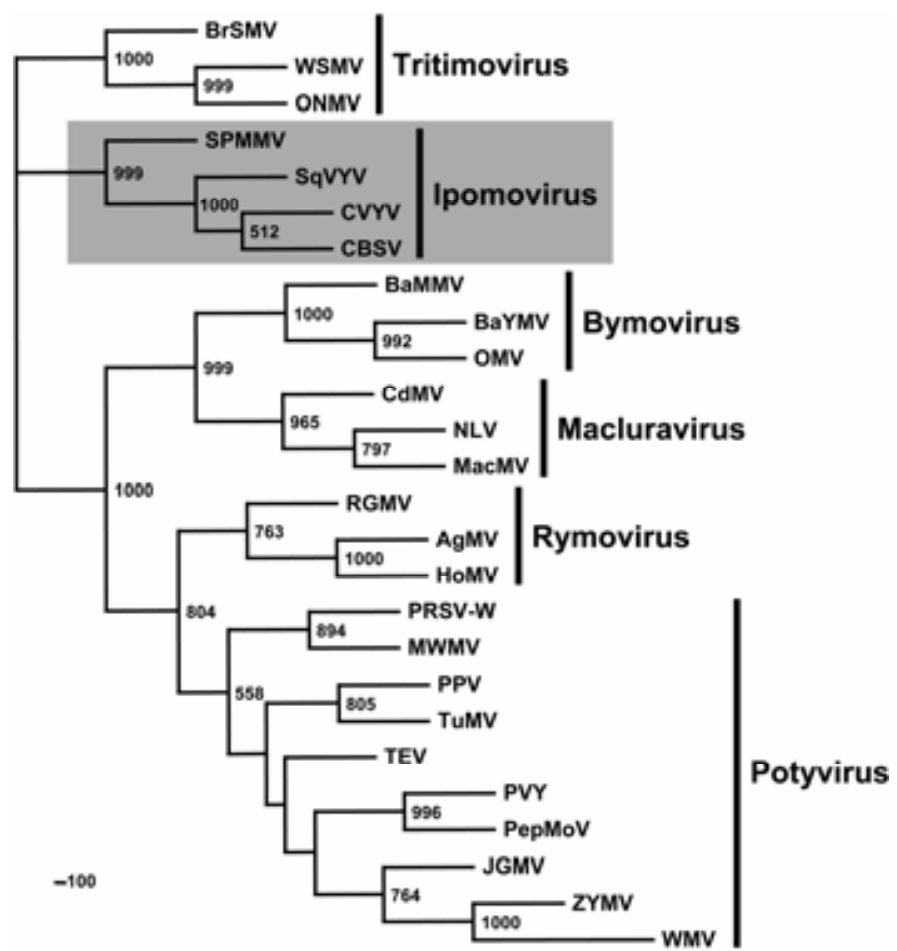

Fig. 6. Phylogenetic analysis of the amino acid sequences of the conserved core of the coat protein of Squash vein yellowing virus (SqVYV) and other members of the family Potyviridae. Sequences were aligned using CLUSTALX (47) with gap opening and extension penalties of 10 and 0.2 , respectively, and Gonnet series protein weight matrix. Phylogenetic trees were inferred using the JTT model and neighbor-joining method using Phylip version 3.65 (17) with Brome streak mosaic virus (BrSMV) as an outgroup. The significance of the branching order was assessed by bootstrap resampling of 1,000 replicates, and values $\geq 50 \%$ are indicated. Viruses included (listed with abbreviation and GenBank accession number for nucleotide sequence) are Agropyron mosaic virus (AgMV, NC_005903), Barley mild mosaic virus (BaMMV, NC 003483), Barley yellow mosaic virus (BaYMV, AJ132268), Brome streak mosaic virus (BrSMV, NC_003501), Cardamom mosaic virus (CdMV, AF189125), Cassava brown streak virus (CBSV, AY007597), Cucumber vein yellowing virus (CVYV, NC_006941), Hordeum mosaic virus (HoMV, NC_005904), Johnsongrass mosaic virus (JGMV, Z26920), Maclura mosaic virus (MacMV, U58771), Moroccan watermelon mosaic virus (MWMV, AF305545), Narcissus latent virus (NLV, U58770), Oat mosaic virus (OMV, AJ306718), Oat necrotic mottle virus (ONMV, AY377938), Papaya ringspot virus type W (PRSV-W, AY027812), Pepper mottle virus (PepMoV, M96425), Plum pox virus (PPV, NC_001445), Potato virus Y (PVY, X12456), Ryegrass mosaic virus (RGMV, Y09854), Squash vein yellowing virus (SqVYV, DQ812125), Sweet potato mild mottle virus (SPMMV, Z73124), Tobacco etch virus (TEV, M15239), Turnip mosaic virus (TuMV, NC_002509), Watermelon mosaic virus (WMV, NC_006262), Wheat streak mosaic virus (WSMV, AF057533), and Zucchini yellow mosaic virus (ZYMV, L31350). The six recognized genera are indicated, with the ipomoviruses shaded. This is an unrooted tree.

\section{DISCUSSION}

SqVYV appears to be a novel species of the genus Ipomovirus within the family Potyviridae based on several criteria. Isolated virions had a morphology consistent with those of other members of the family Potyviridae (Fig. 2A), and subsequently were used to infect squash, resulting in the originally observed symptoms (Fig. 1A and B). The pinwheel-like (Fig. 2B) and cylindrical inclusions (Fig. 2C and D) found in the phloem tissue (parenchyma and companion cells) of SqVYV-infected tissue have been associated previously with infections by other members of the family Potyviridae (16,42). Similar inclusions also have been observed in tissue infected by other whitefly-transmitted members of the family Potyviridae, including CVYV (25) and Squash yellow leaf curl virus (SYLCV) (56). SqVYV was transmitted by whiteflies (like the recognized ipomoviruses) but was not transmitted by aphids (unlike most of the common cucurbit-infecting members of the family Potyviridae). The CPs of members of the family Potyviridae and, in particular, members of the genus Ipomovirus, were the only sequences producing significant alignments with the deduced SqVYV CP sequence.

The invariant $\mathrm{R}$ and $\mathrm{D}$ residues reported to be involved in virion assembly for all members of the family Potyviridae (48) are found within the conserved core of the SqVYV CP, further supporting placement of SqVYV in this family. Curiously, the SqVYV CP also contains the DAG motif at residues 52 to 54 from its $\mathrm{N}$ terminus. This motif is present very close to (5 to 13 residues from) $(42,43)$ the exposed $\mathrm{N}$ terminus of the $\mathrm{CP}$ and has been linked to aphid transmission in members of the genus Potyvirus $(36,44)$ but is absent in the other ipomoviruses, all of which are whitefly transmitted. However, we have demonstrated that SqVYV is not aphid transmissible, a fact perhaps explained by an incorrect sequence context surrounding the DAG motif (26) or the motif occurring too far from the $\mathrm{N}$-terminus to be exposed (43).

SqVYV is most closely related to, but distinct from, CVYV, with $64 \% \mathrm{CP}$ nucleotide identity, $66 \% \mathrm{CP}$ amino acid identity, $79 \%$ conserved core CP amino acid identity, and 44\% $3^{\prime}$ UTR nucleotide identity. The nucleotide identities of the $\mathrm{CP}$ and $3^{\prime}$ UTR are well below the $76 \%$ levels recently proposed for each by Adams et al. (1) for demarcating species within the family Potyviridae. By earlier and still widely accepted taxonomic convention, the conserved core $\mathrm{CP}$ amino acid identity also is sufficient to place SqVYV within the genus Ipomovirus as a distinct entity within an as-yet-undefined subgroup of species $(24,43)$. Perhaps SqVYV and CVYV are the first two members of a cucurbitinfecting subgroup within the genus Ipomovirus. Members of each of the six currently recognized genera in the family Potyviridae always clustered together in our phylogenetic analyses (Fig. 6). Furthermore, SqVYV always clustered with the genus Ipomovirus.

Although our sequence data clearly place SqVYV within the genus Ipomovirus in the family Potyviridae, definitive designation of SqVYV as a novel species awaits completion and analysis of the SqVYV genome. However, the biological properties of SqVYV reported here already provide further evidence for it being a distinct species (e.g., differences in symptoms caused by SqVYV and CVYV on several key cucurbit species). For instance, SqVYV caused rapid death of all tested watermelon cultivars (Figs. 1C and D and 3A; Table 1), whereas CVYV has not (although it can cause fruit symptoms, as discussed below). Conversely, CVYV has caused rapid death of melon plants (as discussed below), whereas SqVYV induced only transient symptoms, after which it became undetectable. Similarly, SqVYV induced only transient symptoms on the parthenocarpic cucumber cultivar we tested (Sweet Success) (Table 1), although CVYV induced severe symptoms, including chlorosis in older leaves and overall stunting of plants in this type of cucumber (28). 
The rapid death of plants and interior fruit symptoms induced by SqVYV in watermelon are quite striking (Fig. 3). However, it is not without precedent for viruses to affect cucurbits in this manner. CVYV, the most closely related species to SqVYV, has been reported to cause "sudden plant death" in melon (Cucumis melo) and splitting and internal necrosis in watermelon fruit (27). Cucumber green mottle mosaic virus (CGMMV), a tobamovirus species, similarly has been known to induce rind and flesh discoloration in watermelon for nearly 40 years $(7,23)$. In both an early report from Japan (23) and a recent report from Greece (7), symptomatic watermelon fruit were produced on plants grafted to bottle gourd (Langenaria siceraria), and the disease was attributed to the use of CGMMV-infected bottle gourd plants as rootstocks.

Whiteflies were able to transmit SqVYV quite readily to (i) squash in the first experiment after a 1-day acquisition access period on infected plants followed by a 2-day inoculation access period and (ii) both squash and watermelon in the second experiment after an $\approx 2$-day acquisition access period on infected plants followed by a $2-\mathrm{h}$ inoculation access period. Mansour and Al-Musa (28) and Harpaz and Cohen (19) demonstrated whitefly transmission of CVYV after acquisition access periods as short as $30 \mathrm{~min}$. Both studies concluded that CVYV is not efficiently transmitted, based on experiments using either 15 to 20 whiteflies per plant (28) or 30 to 35 whiteflies per plant (19). Both studies suggested a semipersistent mode of transmission, with infectivity being lost after 4 to $6 \mathrm{~h}$. We are planning additional experiments to further characterize the whitefly transmission of SqVYV. Green peach aphids, however, could not transmit SqVYV when given acquisition and inoculation access periods that generally result in transmission of the aphid-transmitted cucurbit potyviruses (52), and did result in transmission of PRSV-Tigre and PRSV-W in these experiments.

The SqVYV inclusions observed by light microscopy were of two types. In epidermal cells, cylindrical inclusions were observed projecting from the plasmalemma of the cell wall (Fig. 4A). This has been seen in other members of the family Potyviridae, such as Pepper mottle virus (10), and correlates nicely with the SqVYV cylindrical inclusions observed by electron microscopy (Fig. 2C and D). No cylindrical inclusions were observed in uninfected tissue (Fig. 4B). In addition, SqVYV inclusions were observed in the phloem tissue (data not shown). This is not typical of the viral inclusions induced by members of the aphid-transmitted genus Potyvirus (10). Interestingly, however, virions and pinwheel inclusions have been found in the phloem tissue in thin sections of tissue infected with the whitefly-transmitted SYLCV (56), a putative member of the family Potyviridae discussed below. Tissue infected with other ipomoviruses should be examined to determine whether the SqVYV-induced light microscopic inclusions are typical of this genus.

Several other types of whitefly-transmitted viruses have been described previously from cucurbits, including Cucurbit yellow stunting disorder virus (CYSDV, a member of the genus Crinivirus) (54) and Watermelon chlorotic stunt virus (WmCSV, a member of the genus Begomovirus) $(21,22)$. There is also the single report of SYLCV, which shows some similarity to SqVYV that we describe here, although it was reported to not infect watermelon (56). For instance, both SqVYV and SYLCV are mechanically transmitted with ease, unlike the commonly occurring criniviruses (like CYSDV) and begomoviruses (like WmCSV). Mechanical transmission alone suggests that SqVYV is not a member of either of these groups; however, RT-PCR with previously described CYSDV primers (39) eliminated this common cucurbit crinivirus species (data not shown) and commercially available hybridization testing (Agdia Inc., Elkhart, IN) eliminated the begomoviruses. Unfortunately, there has been no follow-up report or sequence data on SYLCV to allow further comparison.

Our initial virus surveys over the five most recent growing seasons have detected SqVYV, often in mixed infections with
PRSV-W, in watermelon in southwest and west-central Florida suffering from a vine decline and fruit rot (Fig. 5, lanes 12 to 15). This recently reported disease $(37,38)$ can result in total crop loss when watermelon vines collapse shortly before harvest (Fig. 3D), leaving fruit that is often unmarketable due to rind necrosis and discoloration (Fig. 3E) and flesh that has an undesirable color and taste. Our isolation of SqVYV virions from the original infected squash sample allowed us to test the role of SqVYV in watermelon vine decline. Although seedlings (approximately transplant size) of all tested watermelon cultivars developed systemic wilt and necrosis leading to plant death within 7 to 10 days postinoculation (Fig. 1D and E; Table 1), the more relevant results for field disease came from SqVYV inoculation of older, more mature plants. These greenhouse-grown plants developed not only systemic wilt (Fig. 3A) within 14 days postinoculation but also fruit symptoms, including rind necrosis and discoloration (Fig. 3B) reminiscent of field symptoms of vine decline (Fig. 3D and E). SqVYV was reisolated from these dying plants, demonstrating that it is sufficient to induce vine decline and fruit rind necrosis and discoloration, thereby suggesting that SqVYV is the likely cause of this serious watermelon disease.

\section{ACKNOWLEDGMENTS}

We thank C. Vanderspool, K. Sims, J. Smith, R. Lewis, H. Capobianco, S. Clark, K. Cozine, and M. Miller for their excellent technical assistance; A. Whidden, P. Gilreath, G. McAvoy, and R. Muchovej for providing cucurbit field samples; R. Johnson and N. Gruner for providing cucurbit seed; and B. Bruton, C. Mellinger, I. Kamenova, C. Kousik, D. Lewandowski, C. Maroon-Lango, and E. Hiebert for valuable discussions.

\section{LITERATURE CITED}

1. Adams, M. J., Antoniw, J. F., and Fauquet, C. M. 2004. Molecular criteria for genus and species discrimination within the family Potyviridae. Arch. Virol. 150:459-479.

2. Al-Musa, A. M., Qusus, S. J., and Mansour, A. N. 1985. Cucumber vein yellowing virus on cucumber in Jordan. Plant Dis. 69:361.

3. Altschul, S. F., Madden, T. L., Schäffer, A. A., Zhang, J., Zhang, Z., Miller, W., and Lipman, D. J. 1997. Gapped BLAST and PSI-BLAST: A new generation of protein database search programs. Nucleic Acids Res. 25:3389-3402.

4. Berger, P. H., Adams, M. J., Barnett, O. W., Brunt, A. A., Hammond, J., Hill, J. H. Jordan, R. L., Kashiwazaki, S., Rybicki, E., Spence, N., Stenger, D. C., Ohki, S. T., Uyeda, I., van Zaayen, A., Valkonen, J., and Vetten, H. J. 2005. Virus Taxonomy-Classification and Nomenclature of Viruses. Pages 819841 in: 8th Rep. ICTV. C. M. Fauquet, M. A. Mayo, J. Maniloff, U. Desselberger, and L. A. Ball, eds. Elsevier Academic Press, San Diego, CA.

5. Blair, M. W., Bassett, M. J., Abouzid, A. M., Hiebert, E., Polston, J. E., McMillan, R. T., Jr., Graves, W., and Lamberts, M. 1995. Occurrence of bean golden mosaic virus in Florida. Plant Dis. 79:529-533.

6. Blancard, D., Lecoq, H., and Pitrat, M. 1994. Pages 238-253 in: A Colour Atlas of Cucurbit Diseases. Observation, Identification and Control. Manson Publishing, London.

7. Boubourakas, I. N., Hatziloukas, E., Antignus, Y., and Katis, N. I. 2004. Etiology of leaf chlorosis and deterioration of the fruit interior of watermelon plants. J. Phytopathol. 152:580-588.

8. Brako, L., Rossman, A. Y., and Farr, D. F. 1995. Scientific and Common Names of 7,000 Vascular Plants in the United States. The American Phytopathological Society, St. Paul, MN.

9. Chen, J., McAuslane, H. J., Carle, R. B., and Webb, S. E. 2004. Effects of Bemisia argentifolii (Homoptera: Aleyrodidae) infestation and squash silverleaf disorder on zucchini yield and quality. J. Econ. Entomol. 97:2083-2094.

10. Christie, R. G., and Edwardson, J. R. 1994. Light and electron microscopy of plant virus inclusions. Monograph 9, revised. University of Florida, Institute of Food and Agricultural Sciences.

11. Cohen, S, and Nitzany, F. E. 1960. A whitefly-transmitted virus of cucurbits in Israel. Phytopathol. Mediterr. 1:44-46.

12. Colinet, D., Kummert, J., and Lepoivre, P. 1996. Molecular evidence that the whitefly-transmitted sweet potato mild mottle virus belongs to a distinct genus of the Potyviridae. Arch. Virol. 141:125-135.

13. Colinet, D., Kummert, J., and Lepoivre, P. 1998. The nucleotide sequence and genome organization of the whitefly transmitted sweet potato mild mottle virus: A close relationship with members of the family Potyviridae. Virus Res. 53:187-196. 
14. Coutts, B. A., and Jones, R. A. C. 2005. Incidence and distribution of viruses infecting cucurbit crops in the Northern Territory and Western Australia. Australian J. Agric. Res. 56:847-858.

15. Cuadrado, I. M., Janssen, D., Velasco, L., Ruiz, L., and Segundo, E. 2001. First report of Cucumber vein yellowing virus in Spain. Plant Dis. 85:336.

16. Edwardson, J. R., and Christie, R. G. 1996. Cylindrical Inclusions. Bull. 894. University of Florida, Institute of Food and Agricultural Sciences.

17. Felsenstein, J. 1989. PHYLIP-Phylogeny Inference Package. Version 3.2. Cladistics 5:64-166

18. Gibbs, A., and Mackenzie, A. 1997. A primer pair for amplifying part of the genome of all potyvirids by RT-PCR. J. Virol. Methods 63:9-16.

19. Harpaz, I., and Cohen, S. 1965. Semipersistent relationship between cucumber vein yellowing virus (CVYV) and its vector, the tobacco whitefly (Bemisia tabaci Gennadius). Phytopathol. Z. 54:240-248.

20. Janssen, D., Martín, G., Velasco, L., Gómez, P., Segundo, E., Ruiz, L., and Cuadrado, I. M. 2005. Absence of a coding region for the helper component-proteinase in the genome of the cucumber vein yellowing virus, a whitefly-transmitted member of the Potyviridae. Arch. Virol. 150:1439-1447.

21. Jones, P., Satar, N. W., and Alkaff, N. 1988. The incidence of virus disease in watermelon and sweetmelon crops in the Peoples Democratic Republic of Yemen and its impact on cropping policy. Asp. Appl. Biol. 17:203-207.

22. Kheyr-Pour, A., Bananej, K., Dafalla, G. A., Caciagli, P., Noris, E., Ahoonmanesh, A., Lecoq, H., and Gronenborn, B. 2000. Watermelon chlorotic stunt virus from the Sudan and Iran: Sequence comparisons and identification of a whitefly-transmission determinant. Phytopathology 90:629-635.

23. Komuro, Y., Tochihara, H., Fukatsu, R., Nagai, Y., and Yoneyama, S. 1971. Cucumber green mottle mosaic virus (watermelon strain) in watermelon and its bearing on deterioration of watermelon fruit known as konnyaku disease. Ann. Phytopathol. Soc. Jpn. 37:34-42.

24. Lecoq, H., Dafalla, G., Desbiez, C., Wipf-Scheibel, C., Delécolle, B., Lanina, T., Ullah, Z., and Grumet, R. 2001. Biological and molecular characterization of Moroccan watermelon mosaic virus and a Potyvirus isolate from Eastern Sudan. Plant Dis. 85:547-552.

25. Lecoq, H., Desbiez, C., Delécolle, B., Cohen, S., and Mansour, A. 2000. Cytological and molecular evidence that the whitefly-transmitted Cucumber vein yellowing virus is a tentative member of the family Potyviridae. J. Gen. Virol. 81:2289-2293.

26. López-Moya, J. J., Wang, R. Y., and Pirone, T. P. 1999. Context of the coat protein DAG motif affects potyvirus transmissibility by aphids. J. Gen. Virol. 80:3281-3288.

27. Louro, D., Quinot, A., Neto, E., Fernandes, J. E., Marian, D., Vecchiati, M., Caciagli, P., and Vaira, A. M. 2003. Occurrence of Cucumber vein yellowing virus in cucurbitaceous species in southern Portugal. Plant Pathol. 53:241

28. Mansour, A., and Al-Musa, A. 1993. Cucumber vein yellowing virus; host range and virus vector relationships. J. Phytopathol. 137:73-78.

29. McGrath, M. T. 2004. Pages 455-510 in: Diseases of Fruits and Vegetables-Diagnosis and Management, Vol. I. S. A. M. H. Naqvi, ed. Kluwer Academic Publishers, Dordrecht, The Netherlands.

30. Navas-Castillo, J., Albiach-Marti, M. R., Gowda, S., Hilf, M. E., Garnsey, S. M., and Dawson, W. O. 1997. Kinetics of accumulation of citrus tristeza virus RNAs. Virology 228:92-97.

31. Nicholas, K. B., and Nicholas, H. B., Jr. 1997. GeneDoc: A Tool for Editing and Annotating Multiple Sequence Alignments. Pittsburgh Supercomputing Center, Pittsburgh.

32. Page, R. D. M. 1996. TREEVIEW: An application to display phylogenetic trees on personal computers. Comput. Appl. Biosci. 12:357-358.

33. Polston, J. E., and Anderson, P. K. 1997. The emergence of whiteflytransmitted geminiviruses in tomato in the western hemisphere. Plant Dis. 81:1358-1369.
34. Provvidenti, R. 1996. Pages 37-45 in: Compendium of Cucurbit Diseases T. A. Zitter, D. L. Hopkins, and C. E. Thomas, eds. The American Phytopathological Society, St. Paul, MN.

35. Reynolds, E. S. 1963. The use of lead citrate at high $\mathrm{pH}$ as an electron dense stain for electron microscopy. J. Cell Biol. 17:208-212.

36. Riechmann, J. L., Laín, S., and García, J. A. 1992. Highlights and prospects of Potyvirus molecular biology. J. Gen. Virol. 73:1-16.

37. Roberts, P., Muchovej, R., Urs, R., Achor, D., Baker, C., Bruton, B., and Adkins, S. 2005. Investigation into a mature watermelon vine decline and fruit rot. (Abstr.) Phytopathology 95(suppl.):S89.

38. Roberts, P., Muchovej, R. M., Gilreath, P., McAvoy, G., Baker, C. A., and Adkins, S. 2004. Mature vine decline and fruit rot of watermelon. Citrus Veg. Mag. December:12.

39. Rubio, L., Abou-Jawdah, Y., Lin, H.-X., and Falk, B. W. 2001. Geographically distant isolates of the crinivirus Cucurbit yellow stunting disorder virus show very low genetic diversity in the coat protein gene. J. Gen. Virol. 82:929-933.

40. Sambrook, J., and Russell, D. W. 2001. Molecular Cloning: A Laboratory Manual. 3rd ed. Cold Spring Harbor Laboratory, Cold Spring Harbor, NY.

41. Schneider, H. 1981. Pages 315-373 in: Staining Procedures for Biological Stain Commission, 4th ed. G. Clark, ed. Williams and Wilkins, Baltimore.

42. Shukla, D. D., Frenkel, M. J., and Ward, C. W. 1991. Structure and function of the Potyvirus genome with special reference to the coat protein coding region. Can. J. Plant Pathol. 13:178-191.

43. Shukla, D. D., and Ward, C. W. 1989. Structure of potyvirus coat proteins and its application in the taxonomy of the potyvirus group. Adv. Virus Res. 36:273-314.

44. Shukla, D. D., Ward, C. W., and Brunt, A. A. 1994. The Potyviridae. CAB International, Wallingford, UK.

45. Spurr, A. R. 1969. A low-viscosity epoxy resin embedding medium for electron microscopy. J. Ultrastruct. Res. 26:31-43.

46. Teakle, D. S., and Pares, R. D. 1977. Pages 311-315 in: The Atlas of Insect and Plant Viruses. K. Maramorosch, ed. Academic Press, New York.

47. Thompson, J. D., Gibson, T. J., Plewniak, F., Jeanmougin, F., and Higgins, D. G. 1997. The ClustalX Windows interface: Flexible strategies for multiple sequence alignment aided by quality analysis tools. Nucleic Acids Res. 24:4876-4882.

48. Urcuqui-Inchima, S., Haenni, A.-L., and Bernardi, F. 2001. Potyvirus proteins: A wealth of functions. Virus Res. 74:157-175.

49. U.S. Department of Agriculture-National Resources Conservation Service (USDA-NRCS). 2006. The PLANTS Database. National Plant Data Center, Baton Rouge, LA. Published Online by the USDA-NRCS.

50. Waterworth, H. E., Lawson, R. H., and Monroe, R. L. 1976. Purification and properties of hibiscus chlorotic ringspot virus. Phytopathology 66:570-575

51. Webb, S. E., Hiebert, E., and Kucharek, T. A. 2003. Identity and distribution of viruses infecting cucurbits in Florida. (Abstr.) Phytopathology 93(suppl.):S89.

52. Webb, S. E., and Kok-Yokomi, M. L. 1993. Transmission of cucurbit potyviruses by Uroleucon pseudambrosiae (Homoptera: Aphididae), an aphid trapped during epidemics of watermelon mosaic virus 2 in Florida. J. Econ. Entomol. 86:1786-1792.

53. Whidden, A., and Webb, S. 2004. Virus in yellow squash in Hillsborough County. Vegetarian 4 (1). Horticultural Sciences Department, Vegetable Crops Extension Newsletter, University of Florida, Gainesville.

54. Wisler, G. C., Duffus, J. E., Liu, H. Y., and Li, R. H. 1998. Ecology and epidemiology of whitefly-transmitted closteroviruses. Plant Dis. 82:270280.

55. Yilmaz, M. A., Ozaslan, M., and Ozaslan, D. 1989. Cucumber vein yellowing virus in Cucurbitaceae in Turkey. Plant Dis. 73:610.

56. Zouba, A. A., Lopez, M. V., and Anger, H. 1998. Squash yellow leaf curl virus: A new whitefly-transmitted poty-like virus. Plant Dis. 82:475-478. 